\title{
Genome sizes of all 19 Araucaria species are correlated with their geographical distribution
}

\author{
B. J. M. Zonneveld
}

Received: 30 August 2011/Accepted: 31 March 2012/Published online: 26 April 2012

(C) The Author(s) 2012. This article is published with open access at Springerlink.com

\begin{abstract}
Nuclear genome size was determined to investigate the relationships between all 19 species of Araucaria de Jussieu. Species from the two other genera of Araucariaceae, Wollemia and Agathis, were also studied. The genome size of 17 out of the 19 species of Araucaria are reported here for the first time. All Araucariaceae have the same chromosome number $2 n=26$. However, the nuclear DNA contents (2C value) for Araucaria range from 31.3 to $45.4 \mathrm{pg}$. There is a good correlation between genome size and division in sections, and geographical distribution. The two species from South America have 44.7 and $45.4 \mathrm{pg}$, the two species from Australia have 35.7 and $44.4 \mathrm{pg}$ and the two species from New Guinea 34.7 and 40.4 pg. All 13 species of New Caledonia and the one from Norfolk Island have a similar, if not identical, amount of nuclear DNA of, on average, $31.9 \mathrm{pg}$. This corroborates the identical DNA $r b c \mathrm{~L}$ sequences found for the New Caledonian araucarias. It suggests that the species from New Caledonia diversified more recently and it questions their status as separate species. Compared with this $31.9 \mathrm{pg}$ a strong increase seems to have occurred in the genome size of the "mainland" araucarias. Genome sizes are evaluated and compared with available taxonomic treatments and extant geographic spreading. The nuclear DNA contents found within the sections are close, making it possible to assign an unknown plant to a section. A difference of $1 \mathrm{pg}$, which amounts to a difference of $978 \mathrm{Mbp}$, far exceeds a single character. Nuclear DNA content, as measured by flow cytometry, may conveniently be used to produce
\end{abstract}

B. J. M. Zonneveld ( $\square)$

Herbarium Section, NBC Naturalis, P.O. Box 9514,

2300 RA Leiden, The Netherlands

e-mail: Zonneveld@NHN.Leidenuniv.nl systematic data. It is applicable even with young plants or seeds for monitoring the trade in endangered species.

Keywords Araucaria - Genome size - DNA 2C value Taxonomy · Geography

\section{Introduction}

Conifers are economically very important. They are not only sources of timber but also of wood pulp and resins. Both Araucaria and the genus Pinus L. also provide edible seeds (Zonneveld 2011).

The conifers were divided by Pilger (1926) into seven families. However Eckenwalder (1976) argued that the Taxodiaceae should be merged with Cupressaceae and that Sciadopitys Siebold and Zucc. should be placed in a separate family. One of the now eight families is the Araucariaceae with two genera: Araucaria de Jussieu and Agathis Salisbury. Recently (1994) a third genus in the Araucariaceae, Wollemia Jones, Hill an Allen was found in Australia. Two valuable books covering all extant conifers are now available: that of Eckenwalder (2009) and that of Farjon (2010). In these books the number of Araucaria species is set at 19, the number of Agathis species at 15 or 17, and there is one species of Wollemia.

The Araucariaceae have an ancient origin and are a distinctive component of southern hemisphere forests. From an origin in the Triassic the family expanded in both hemispheres and remained an important component of the vegetation until the late Cenozoic. Seedcone scales indistinguishable from those of $A$. heterophylla have recently been found in the Upper Maastrichtian, ca 65 MYBP old (van der Ham et al. 2010). Continental separation and climatic drying reduced the ranges of conifers to moist 
mesothermal climates (Kershaw and Wagstaff 2001). Thirteen of the 19 species of Araucaria are found on New Caledonia that separated from Australia approximately 65 MYBP. New Caledonia is located approximately $1,200 \mathrm{~km}$ from Australia and 1,500 km from New Zealand. The flora of New Caledonia is characterized by the presence of a large number of lineages that seem to represent remnants of the Gondwana flora once covering a large part of Australasia.

During the Tertiary (40-45 MYBP) New Caledonia underwent a series of submersions, covering the island with peridotites, formed from ocean crust, and to a lesser extent with serpentine soil. These soils are ultrabasic and have a high content of heavy metals, for example iron and nickel, making them rather toxic to most plants. The ultrabasic soils enabled the older lineages to adapt and survive in a sort of local refugium (Thorne 1965). So it comes as no surprise that, among the 1,176 species in New Caledonia that occur exclusively on ultrabasic soils, $98 \%$ are endemic (Lowry 1998). These ultrabasic soils presented the initial vegetation with ecological conditions that were favourable for subsequent speciation, as seen in the now 13 species of Araucaria. This is also born out by the fact that 43 of the 44 native species of gymnosperms are endemic (de Laubenfels 1972).

To elucidate the relationships between Araucaria species further, the taxonomic traits based on morphological characters, geographical distribution, and molecular data are here supplemented with data on nuclear DNA content. Earlier, Agathis australis (D.Don) Lindl. was measured with $2 \mathrm{C}=31.6 \mathrm{pg}$ (Davies et al. 1997). Three araucarias were also measured: A. cookii R.Br. ex Lindl.(=A. cunninghamii Aiton ex A.Cunn.) with 19.1 pg, Araucaria robusta (Agathis robusta?) with $21.6 \mathrm{pg}$, and A. cunninghamii with 21.8 pg (Ohri and Khoshoo 1986). These araucarias were measured with Feulgen densitometry, a method that is not very reliable if not properly handled (Greilhuber and Temsch 2001).

Nuclear DNA content can conveniently be measured by flow cytometry using propidium iodide, a stoichiometric DNA stain that intercalates in the double helix. Where all species in a genus have the same chromosome number as in the Araucariaceae (Khoshoo 1961), differences in genome size have proved to be very effective in delimiting infrageneric subdivisions (Ohri 1998). Greilhuber (2005) clearly showed that there is, in general, much less intraspecific variation of genome size than previously expected. Evolution of genome size has received increased attention in recent years. The smallest angiosperm genome size reported so far is for Genlisia margarethae Hutch. (Lentiburaliaceae) with $2 \mathrm{C}=0.13 \mathrm{pg}$ (Greilhuber et al. 2006) (now renamed $G$. aurea-the true G. margarethae has $2 \mathrm{C}=0.36 \mathrm{pg}$, Greilhuber personal communication). The record holders for maximum genome size were, for eudicots, Viscum album L. with $2 \mathrm{C}=205.8 \mathrm{pg}$ and, for monocots, Trillium hagae Miyabe and Tatew. (Melanthiaceae) with $264.9 \mathrm{pg}$ (Zonneveld 2010a, b). The latter value was, a few months later, superseded by the octoploid Paris japonica (Melanthiaceae) with 2C $=304.5 \mathrm{pg}$ (Pellicer et al. 2010). Flow cytometry has been successfully used to measure genome size for the genera Hosta Tratt., Helleborus L., Galanthus L., Narcissus L., Tulipa L., Eucomus L'Hér., and Hepatica Mill, etc. by Zonneveld (2001, 2008, 2009, 2010a, b, 2011), Zonneveld and Van Iren (2001), Zonneveld and Duncan (2010), and Zonneveld et al. (2003). In the work discussed in this paper all 19 species of Araucaria were measured and the correlation of their genome size with geographical spreading is demonstrated. Genome size alone is sufficient to ascribe a species of Araucaria to its section and in most cases to its geographic origin.

\section{Materials and methods}

\section{Plant material}

Plant material was obtained from the collections of the Botanical Garden of Bochum Germany, the Arboretum Trompenburg Rotterdam, the Pinetum Blijdenstein Hilversum, the Botanical Garden of Leiden, and from commerce, all from the Netherlands. Care was taken to ensure correct identification of all material.

\section{Flow cytometric measurement of DNA 2C value}

Conifer needles are relatively difficult to chop. So, if possible, young leaves or buds were used to isolate nuclei. These were chopped together with a piece of Agave americana L. "Aureomarginata" as internal standard (see below). The material was chopped with a new razor blade in a Petri dish in $0.25 \mathrm{ml}$ nuclei-isolation buffer to which $0.25 \mathrm{mg} \mathrm{RNase} / \mathrm{ml}$ had been added (Zonneveld and van Iren 2001). After adding $1.75 \mathrm{ml}$ propidium iodide solution (50 mg PI/l in isolation buffer) the suspension with nuclei was filtered through a $30-\mu \mathrm{m}$ nylon filter. The fluorescence of the nuclei was measured half an hour and one hour after addition of propidium iodide, by use of a Partec CA-II flow cytometer. The optical path contained a HBO mercury lamp, filters KG1 and BG12, dichroic mirror TK500, filter OG570, and a Leitz $50 \times 1$ water-immersion objective. Data were analysed by means of DPAC software (Partec). The 2C DNA content of the sample was calculated as the sample peak mean, divided by the Agave peak mean, and multiplied with the amount of DNA of the Agave standard. Usually two different samples, with each at least 5,000 
nuclei, were measured twice for each accession. Most histograms revealed a coefficient of variation of less than $5 \%$.

Internal standard and absolute DNA content

When measuring nuclear DNA content by flow cytometry it is necessary to chop tissue from the plant of interest together with an internal standard. This standard must be as close as possible to the plants of interest. In this way, variation in signal intensities because of staining kinetics, light absorption, quenching by sample components, and instrumental and other variables, is reduced to a minimum. Agave americana was chosen as internal standard for Araucaria. They are available year-round, keep fresh for several weeks without water, and, because they are large plants, a single specimen can serve a lifetime, thereby further reducing variation in readings. They also have a low background in propidium iodide measurements, a single $\mathrm{G}_{0}$ peak, and are almost lacking $\mathrm{G}_{2}$ arrest.

Fresh male human leucocytes $(2 \mathrm{C}=7.0 \mathrm{pg} ; 1 \mathrm{pg}=$ $10^{-12} \mathrm{~g}=0.978 \times 10^{9}$ base pairs; Doležel et al. 2003) were chosen as primary standard (Tiersch et al. 1989). This yields $2 \mathrm{C}=15.9 \mathrm{pg}$ for nuclei of Agave americana $\mathrm{L}$. On the basis of a published male human genome size of $6.294 \times 10^{9}$ base pairs the nucleus was calculated as containing $6.436 \mathrm{pg}$ (Doležel et al. 2003). However this is based on a human sequence for which the size of the very large repeat sequences could not accurately be determined, so the genome size could be closer to $7 \mathrm{pg}$ than now envisaged.

\section{Results and discussion}

\section{Araucariaceae}

According to DNA evidence (Quinn et al. 2002; Kunzmann 2007; Rai et al. 2008; Liu et al. 2009) Podocarpaceae are close to Araucariaceae with Pinaceae at the base of the Coniferales. However the fossil record (Farjon 2010) points to a basal position of Podocarpaceae + Araucariaceae. Assuming an increase in DNA with time, the small genome sizes for the Podocarpaceae, with, on average, 13 pg (Zonneveld 2012, in press) (but not for the Araucariaceae) points indeed to an ancient position for the Podocarpaceae.

With three genera and 35 species, Araucariaceae are one of the smaller families of conifers. Molecular phylogeny (Gilmore and Hill 1997; Quinn et al. 2002; Rai et al. 2008; Liu et al. 2009) found Wollemia to be the sister group of Agathis, and Araucaria sister to both. This suggests that both increases and decreases in nuclear DNA content have occurred in the long history of the Araucariaceae. This placement was not found by Setoguchi et al. (1998), the only publication on DNA sequencing of all 19 species. He found Wollemia basal to Agathis and Araucaria, probably because of their different choice of outgroups. The three genera of Araucariaceae are readily distinguished by their leaf arrangement on side branches-in Araucaria de Jussieu the leaves are spirally placed, in Agathis Salisbury the leaves are opposite and distichously placed, and in Wollemia Jones, Hill and Allen the leaves are opposite and placed in four rows.

Nuclear DNA content (2C value; genome size $=1 \mathrm{C}$ value) was measured for all 19 species of Araucaria. For comparison, Wollemia nobilis and Agathis dammara (Lamb.) Rich. and A.Rich. were also measured. Genome sizes of only 2 of the 19 species of Araucaria were reported before (Murray et al. 2010). Genome size as investigated here (Table 1), complements work based on morphological characters and evidence from DNA sequencing. Despite the same chromosome number for all Araucariaceae the nuclear amount of DNA ranges from 31.3 to $45.4 \mathrm{pg}$. This difference of $14 \mathrm{pg}$ is equivalent to approximately $1.4 \times 10^{10}$ base pairs. The species are arranged in Fig. 1 and Table 1 according to their systematic classification and geographic distribution. This reveals the relationship between genome size, sectional division, and geographic spreading.

\section{Araucaria de Jussieu}

Araucaria fossils from more than 200 million years ago have been found, and the genus had worldwide tropical distribution in Gondwana. They became extinct in the northern hemisphere after the Uppermost Cretaceous (van der Ham et al. 2010) and became restricted to their present southern distribution in the Tertiary (Eckenwalder 2009). Araucaria has a disjunct distribution with two species in South America and the other 17 species in Australasia, a characteristic feature of Gondwanan relict species. They are usually divided in four sections that are distributed as follows: Section Eutacta New Caledonia (13 sp), Norfolk Island (1 sp.), and Australia/New Guinea (1 sp.); Section Araucaria: Brazil (1 sp), Chile (1 sp.); section Bunya: Australia (1 sp.), and section Intermedia: New Guinea (1 sp.). In other words, New Caledonia has 13 species, South America, Australia and New Guinea two species each, and Norfolk Island one species.

Were it not for the fossil record, three of the four sections with, in total, four species might well be merged in a single section Araucaria s.l (Eckenwalder 2009). However the same fossil record found that section Bunya was the oldest and this is not supported by DNA analyses. The fossil record also showed that of seven Tertiary fossil 
Table 1 Nuclear DNA content (2C) of all species of Araucaria with standard deviation, origin, and the source of the material

\begin{tabular}{|c|c|c|c|c|}
\hline Species of Araucariaceae & $\begin{array}{l}\text { pg DNA }(2 \mathrm{C}) \\
\text { per nucleus }\end{array}$ & SD & Origin & Source \\
\hline \multicolumn{5}{|l|}{ Araucaria } \\
\hline \multicolumn{5}{|l|}{ Section Araucaria } \\
\hline A. angustifolia (Bertol.) Kuntze & 44.7 & 0.9 & Brazil/Argentina & Ex commerce \\
\hline A. araucana (Molina) K.Koch & 45.5 & 1.1 & Chile/Argentina & Ex commerce \\
\hline \multicolumn{5}{|l|}{ Section Bunya } \\
\hline A. bidwillii Hook. & 44.4 & 0.8 & Australia & BG Barcelona \\
\hline \multicolumn{5}{|l|}{ Section Intermedia } \\
\hline A. hunsteinii K. Schum. & 40.4 & 0.7 & New Guinea & BG Trompenburg \\
\hline \multicolumn{5}{|l|}{ Section Eutacta } \\
\hline A. cunninghamii Aiton ex A.Cunn. & 35.7 & 0.6 & NE Australia & BG Leiden \\
\hline A. cunninghamii var. papuana & 34.7 & 0.4 & $\begin{array}{l}\text { McAdams N. Park } \\
\text { New Guinea }\end{array}$ & BG Leiden \\
\hline A. heterophylla (Salisb.) Franco & 32.5 & 0.5 & Norfolk Island & Ex commerce \\
\hline A. bernieri J.T.Buchholz & 32.2 & 0.6 & New Caledonia & BG Bochum \\
\hline A. biramulata J.T.Buchholz & 32.0 & 0.7 & New Caledonia & BG Bochum \\
\hline A. columnaris (J.R.Forst.) Hook. & 31.5 & 0.4 & New Caledonia & BG Bochum \\
\hline A. humboldtensis J.T.Buchholz & 32.2 & 0.5 & New Caledonia & BG Bochum \\
\hline A. laubenfelsii Corbasson & 31.9 & 0.0 & New Caledonia & Pin. Blijdenstein \\
\hline A. luxurians (Brongn.\&Gris) de Laub. & 31.8 & 0.9 & New Caledonia & BG Bochum \\
\hline A. montana Brongn.\& Gris & 32.1 & 0.7 & New Caledonia & Pin. Blijdenstein \\
\hline A. muelleri (Carriere) Brongn. \& Gris & 31.3 & 1.2 & New Caledonia & BG Bochum \\
\hline A. nemorosa de Laub. & 31.7 & 0.2 & New Caledonia & Pin. Blijdenstein \\
\hline A. rulei F.Muell. 'Elegans' & 32.3 & 0.5 & New Caledonia & Pin. Blijdenstein \\
\hline A. schmidii de Laub. & 32.0 & 0.7 & New Caledonia & BG Bochum \\
\hline A. scopulorum de Laub. & 31.7 & 0.4 & New Caledonia & BG Bochum \\
\hline A. subulata Vieill. & 31.9 & 0.2 & New Caledonia & Pin. Blijdenstein \\
\hline \multicolumn{5}{|l|}{ Agathis } \\
\hline Agathis dammara (Lamb.) Rich. & 26.9 & 0.7 & Indonesia/Malaysia & BG Leiden \\
\hline \multicolumn{5}{|l|}{ Wollemia } \\
\hline Wollemia nobilis W.G.Jones et al. & 28.4 & 0.1 & E. Australia & BG Leiden \\
\hline
\end{tabular}

species of Australia five could be placed in section Eutacta and two in section Araucaria, seemingly obviating the need for extra sections (Hill 1990).

If Araucaria is divided into two sections only, as already done by de Laubenfels (1972), they could be morphologically characterized as a section Araucaria s.l. with flat and straight leaves, pollen and seed cones axillary, four cotyledons, and mainly hypogeal germination (four species, type A. araucana) and section Eutacta (Link) Endl. with scaly or needle-like and curled leaves, pollen and seed cones terminally, two cotyledons, and epigeal germination (15 species, type A. cunninghamii)(de Laubenfels 1972). This division into two sections would not only be in accordance with earlier cladograms (Gilmore and Hill 1997; Quinn et al. 2002; Rai et al. 2008; Liu et al. 2009) but also with genome sizes, with $31.3-35.2 \mathrm{pg}$ for section
Eutacta and 40.4-45.4 pg for section Araucaria s.l. For ease of discussion the division into four sections is used here.

\section{Section Eutacta}

This section has 13 species from New Caledonia with 31.3-32.3 pg (average $31.9 \mathrm{pg}$ ). These values, lower than for any of the other araucarias, make it unlikely they were derived after recolonization from Australia. Basal to this group is A. heterophylla (Salisb.) Franco, used worldwide as a house plant, from Norfolk Island with $32.5 \mathrm{pg}$, indicating a close relationship. These in turn have A. cunninghamii Aiton ex A.Cunn. as a basal species with $35.2 \mathrm{pg}$ (Setoguchi et al. 1998). A. cunninghamii is divided in two varieties: var. cunninghamii from Australia with 35.7 pg 


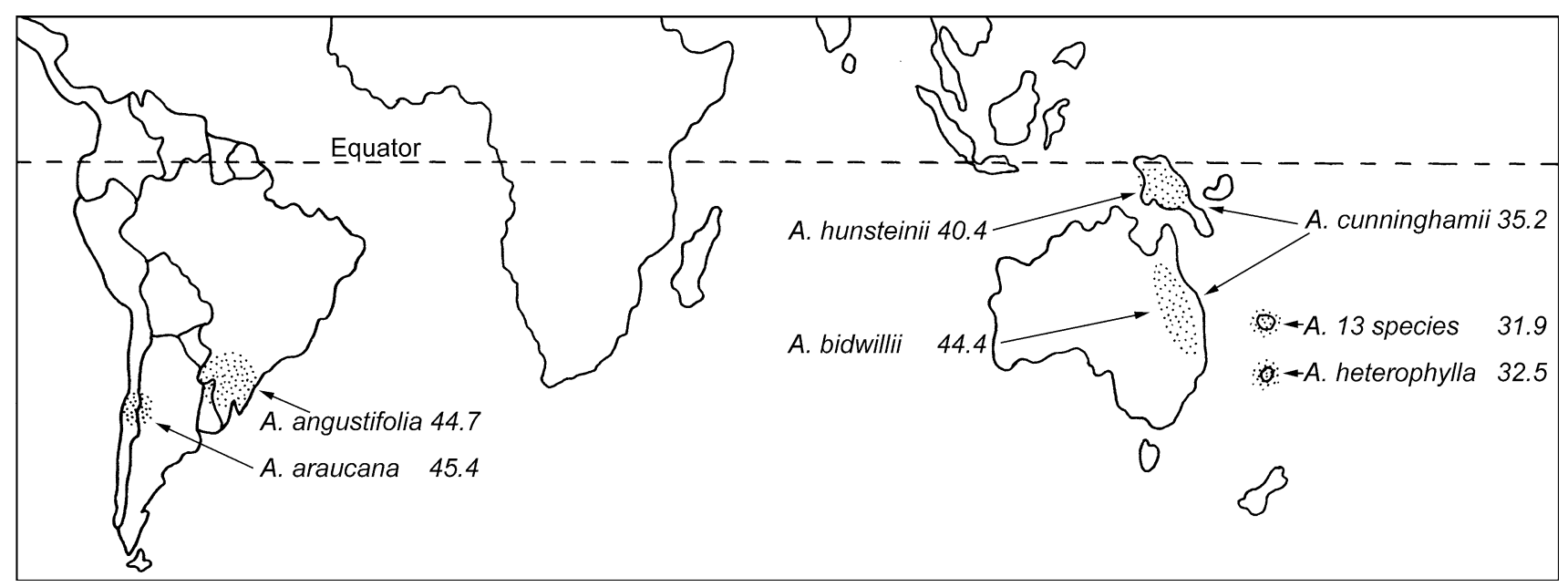

Fig. 1 Geographical distribution of all Araucaria species, followed by their nuclear DNA content in pg, and arranged according to their section. From left to right: Section Araucaria: A. angustifolia (Brazil, Argentina, Paraguay), A. araucana (Chile, Argentina), Section Intermedia: A. hunsteinii (New Guinea) Section Bunya: A. bidwillii

and var. papuana from New Guinea with $34.7 \mathrm{pg}$. It could be a coincidence, but the genome size of the Australian/ New Guinean A. cunninghamii with $2 \mathrm{C}=35.2 \mathrm{pg}$ is intermediate between the New Caledonian species with $31.9 \mathrm{pg}$ and the New Guinean A. hunsteinii with $40.4 \mathrm{pg}$.

The 13 species occurring in New Caledonia, belonging to section Eutacta, are primarily restricted to ultrabasic soil, with exception of A. columnaris, which is found along the coast on coral remains. De Laubenfels (1972) remarks that the 13 species of New Caledonia differ in size and shape of the adult leaves and in the shape of the male cones, but hardly in any other character. Without the age of the tree and the height where it grows, it is even impossible to distinguish a branch with young leaves of species A from a branch with adult leaves of species B. Coupled with near identical $r b c \mathrm{~L}$ genes and near identical genome sizes one wonders if the union of these 13 species into a single species (with different subspecies) would not better represent affinities within the genus Araucaria. However, from a conservation standpoint 13 species might be preferable.

\section{Section Bunea}

This section has only one species A. bidwillii Hook. from Australia. Its range partly overlaps those of $A$. cunninghamii of section Eutacta. According to DNA evidence (Setoguchi et al. 1998) it is placed in the same clade as section Araucaria (with A. araucana (Molina) K. Koch and A. angustifolia (Bertol.) Kuntze) and section Intermedia (with A. hunsteinii K. Schum.). These four species are sister to the other araucarias from section Eutacta. The
(E. Australia), Section Eutacta: A. cunninghamii (E. Australia, New Guinea), A. bernieri, biramurata, columnaris, humboldtensis, laubenfelsii, luxurians, montana, muelleri, nemorosa, rulei, schmidii, scopulorum, subulata (13 species, New Caledonia) A. heterophylla (Norfolk Island)

genome size $(2 \mathrm{C}=44.4 \mathrm{pg})$ does not support section Bunya as the oldest section, as is suggested by the fossil record (Stockey and Taylor 1978). Its genome size corroborates the earlier placement in this clade, based on $r b c \mathrm{~L}$ (Setoguchi et al. 1998) and AFLP (Stefenon et al. 2006) analyses.

\section{Section Intermedia}

The single species of this section, A. hunsteinii from New Guinea is, with $89 \mathrm{~m}$, not only the largest of all araucarias, but also the tallest tree of New Guinea. It is somewhat isolated, being placed in a section by itself, because it is intermediate in some characteristics between section Eutacta and the others. Its nuclear DNA content of $40.4 \mathrm{pg}$ shows that it is closely related to the other three species of section Araucaria s.l., all with approximately $45 \mathrm{pg}$. The other Araucaria of New Guinea is A. cunninghamii, placed in section Eutacta and their territories partly overlap.

\section{Section Araucaria}

This section contains two species: A. araucana from Chile, the type plant of Araucaria, and A. angustifolia from S. Brazil, overflowing into adjacent countries. They are close in nuclear DNA content: $45.4 \mathrm{pg}$ for A. araucana and $44.7 \mathrm{pg}$ for $A$. angustifolia and can be crossed successfully. Both species are the only araucarias that are mostly dioecious and are (or were) important timber trees. The large seeds of both, produced abundantly, have been an important food source for local people and wildlife. The common name monkey puzzle tree is somewhat fanciful, because no monkeys live in its native range. 
Agathis Salisb.

Agathis is distributed over Indonesia, Malaysia, the Philippines, Melanesia, Australia, New Zealand, and Fuji.

Resting buds, covered with imbricate scales, are well developed, the petioled leaves are flat, not needle-like, and seeds have a very large wing. Despite its economic importance both for timber and resins there is surprisingly little consensus on an appropriate classification. The characters of the species are all intergrading, so the number of species can vary from 12 to 21 in different classifications and the different groupings of species overlap only a little (Eckenwalder 2009). The only species here measured, Agathis dammara has $2 \mathrm{C}=26.9 \mathrm{pg}$.

\section{Wollemia Jones, Hill an Allen}

The discovery in 1994 of this conifer belonging to the Araucariaceae caused much excitement among botanists (Jones et al. 1995). Wollemia has several characteristics of both Araucaria and Agathis. The fossil record goes back at least a 100 million years making it one of the oldest living conifer genera. There are fewer than 40 unique trees in a single canyon in southeastern Australia. It can be grown from cuttings and via tissue culture and the latter has provided many young plants that can now be obtained worldwide. Setoguchi et al. (1998) place Wollemia basal to Agathis + Araucaria but this might be because of their choice of out-group's. According to other/later DNA studies (Gilmore and Hill 1997; Liu et al. 2009) Wollemia is more similar to Agathis than to Araucaria. This is supported by a genome size of $2 \mathrm{C}=28.4 \mathrm{pg}$ for Wollemia nobilis that is close to Agathis dammara with $26.9 \mathrm{pg}$ and less so to the araucarias varying from $31.3-45.4 \mathrm{pg}$. Wollemia was previously measured (Hanson 2001) with a similar genome size of $2 \mathrm{C}=27.9 \mathrm{pg}$.

\section{Relation of genome size to geographical distribution}

The species are arranged in Fig. 1 according to their taxonomic position and geographic distribution. Figure 1 and Table 1 reveal the relationship between genome sizes, sectional division, and geographic spreading. They clearly show that the sections have similar amounts of DNA. Moreover the species closest in genome size are also geographically closest. The relatively small genome sizes for the section Eutacta suggest that these are the most primitive. Their near identity in DNA analyses (Setoguchi et al. 1998), corroborated by a very similar genome size and a limited morphological diversity, suggest recent radiation. If $32 \mathrm{pg}$ is the basal value for Araucaria, they must have evolved and survived elsewhere by having a strong, nearly $50 \%$ increase in their genome sizes. Maybe only the few that were able to acquire this extra DNA were the extant survivors. This extra DNA might have led to slow but enduring growth making them often the largest trees in the forest. This seems important, maybe essential, for wind pollinated trees. All others might have succumbed to the dryness of the climate and the domination of the angiosperm trees. Although the genome sizes suggest this, it seems unlikely they radiated from the very isolated New Caledonia to other places.

\section{Polyploidy}

Ploidy seems not to have been involved in the speciation of Araucariaceae. The absence of polyploidy might be because araucarias already have a large amount of nuclear DNA, approximately 20 times more than the average angiosperm tree (Ahuja 2005). From A. angustifolia seeds also were available for measurement. The endosperm turns out to be haploid, as for all conifers measured so far (Zonneveld, unpublished results). More peculiar is the fact that the embryo had $50 \%$ of cells with nuclear DNA content inferring tetraploidy.

\section{Conclusion}

Flow cytometry can be regarded as a quick and useful means of producing systematic data. Moreover, it can be used to investigate imported plants, precluding the need to grow them to maturity for identification purposes. The amount of nuclear DNA (2C value) ranges from 31.3-45.4 pg. This almost $50 \%$ difference in DNA content without any difference in the number of chromosomes may be because of genomic changes, for example insertions, but is more likely to be the result of a vast increase in the number of transposable elements. Depending on the size of the total genome, one picogram amounts to several thousand genes. Moreover, the largest genome contains approximately $1.4 \times 10^{10}$ more base pairs than the smallest, and has chromosomes that are, on average, $45 \%$ longer. Therefore, conclusions and suggestions based on genome size seem intrinsically more informative than a single morphological character. The results presented here for genome sizes agree with recent classifications of Araucariaceae and with their geographic distribution. Flow cytometry as a taxonomic and diagnostic tool is applicable even to seeds (Zonneveld 2011), or juvenile plants, and also has applications in conservation monitoring.

Acknowledgments I would like to thank A. Aptroot, G. Fortgens, P. Knopf, H. van Roon, and A. Vogel for their generous supply of plant material. Anita Wallsmit Sachs and B. Kieft are thanked for producing Fig. 1. 
Open Access This article is distributed under the terms of the Creative Commons Attribution License which permits any use, distribution, and reproduction in any medium, provided the original author(s) and the source are credited.

\section{References}

Ahuja MR (2005) Polyploidy in gymnosperms: revisited. Silvae Genetica 54:59-69

Davies BJ, O'Brien IEW, Murray BG (1997) Karyotypes, chromosome bands and genome size variation in New Zealand endemic gymnosperms. Plant Syst Evol 208:169-185

de Laubenfels DJ (1972) Gymnosperms. Flore de la NouvelleCaledonie et Dependances 4:1-168

Doležel J, Bartos J, Voglmayer H, Greilhuber J (2003) Nuclear DNA content and genome size of trout and human. Cytometry 51a:127-128

Eckenwalder JE (1976) Re-evaluation of Cupressaceae and Taxodiaceae: a proposed merger. Madrono 23:237-256

Eckenwalder JE (2009) Conifers of the world: the complete reference. Timber Press

Farjon A (2010) A handbook of the world conifers, vol 1,2. Brill Press, Leiden-Boston, pp 1-1111

Gilmore S, Hill KD (1997) Relationship of the Wollemi pine (Wollemia nobilis) and a molecular phylogeny of the Araucariaceae. Telopea 7:275-291

Greilhuber J (2005) Intraspecific variation in genome size in angiosperms, identifying its existence. Ann Bot 95:91-98

Greilhuber J, Temsch EM (2001) Feulgen densitometry: some observations relevant to best practice in quantitative nuclear DNA content determination. Acta Bot Croatica 60:285-298

Greilhuber J, Borsch T, Muller K, Worberg A, Porembski S, Barthlott W (2006) Smallest angiosperm genomes found in Lentibulariaceae with chromosomes of bacterial size. Plant Biol 95:255-260

Hanson L (2001) Chromosome number, karyotype and DNA C-value of the Wollemi pine (Wollemia nobilis, Araucariaceae). Bot J Linn Soc 135:271-274

Hill RD (1990) Araucaria (Araucariaceae) species from Australian Tertiary sediments: a micromorphological study. Aust Syst Bot 3:203-220

Jones WG, Hill KB, Allen JM (1995) Wollemia nobilis, a new living Australian genus and species in the Araucariaceae. Telopea 3:173-176

Kershaw P, Wagstaff B (2001) The southern conifer family Araucariaceae: History, status, and value for paleoenvironmental reconstruction. Ann Rev Ecol Syst 32:397-414

Khoshoo TN (1961) Chromosome numbers in Gymnosperms. Silvae Genetica 10:1-9

Kunzmann L (2007) Araucariaceae (Pinopsida): Aspects in palaeobiogeography and palaeobiodiversity in the Mesozoic. Zool Anzeiger 246:257-277

Liu N, Zhu Y, Wei ZX, Chen J, Wang QW, Jian SG, Zhou DW, Shi J, Yang Y, Zhong Y (2009) Phylogenetic relationships and divergence times of the family Araucariaceae based on the DNA sequences of eight genes. Chin Sci Bull 54:2648-2655. doi:10.1007/s11434-009-0373-2

Lowry PP (1998) Diversity, endemism and extinction in the flora of New Caledonia: a review. Rare, threatened and endangered floras of Asia and the Pacific Rim. CI Peng and PP Lowry eds. Ac. Sinica monograph ser. 16:181-206

Murray BG, Leitch IJ, Bennett MD (2010) Gymnosperm DNA $C$ values database (release 4.0, Dec. 2010) http://www.kew.org/ cvalues/
Ohri D (1998) Genome size variation and plant systematics. Ann Bot 82(Suppl A):750-812

Ohri D, Khoshoo TN (1986) Genome size in gymnosperms. Plant Syst Evol 153:119-132

Pellicer J, Fay MF, Leitch IJ (2010) The largest eukaryotic genome of them all? Bot J Linn Soc 164:10-15

Pilger R (1926) Klasse Coniferae. In: Engler A, Prantler E (eds) Die naturliche Pflanzenfamilien, vol 3, 2nd edn. W. Engelmann Verlag, Leipzig, pp 121-403

Quinn GJ, Price RA, Gadek PA (2002) Familial concepts and relationships in the conifers based on $r b c \mathrm{~L}$ and $m a t \mathrm{~K}$ sequence comparisons. Kew Bull 57:513-531

Rai HS, Reeves PA, Peakall RG, Olmstead RG, Graham SW (2008) Inference of higher order relationships from a multilocus data set. Botany 86:658-659

Setoguchi H, Osawa TAS, Pintaud JC, Jaffre T, Veillon J (1998) Phylogenetic relationships within Araucariaceae based on $r b c \mathrm{~L}$ gene sequences. Am J Bot 85:1507-1516

Stefenon VM, Hailing O, Finkeldey R (2006) Phylogenetic relationship within genus Araucaria (Araucariaceae) assessed by means of AFLP fingerprints. Silvae Genetica 55:45-52

Stockey RA, Taylor TN (1978) On the structure and evolutionary relationships of the Cerro Quadrado fossil conifer seedlings. Bot J Linn Soc 76:161-176

Thorne RF (1965) Floristic relationships of New Caledonia. Univ Iowa Stud Nat Hist 21:1-14

Tiersch TR, Chandle RW, Wachtel SSM, Ellias S (1989) Reference standards for flow cytometry and application in comparative studies of nuclear DNA content. Cytometry 10:706-710

van der Ham RWJM, Jagt JWM, Renkens J, Van Konijnenburg-van Cittert JHA (2010) Seedcone scales from the upper Maastrichtian document the last occurrence in Europe of the southern hemisphere conifer family Araucariaceae. Palaeogeography, Palaeoclimatology, Palaeoecology 291:469-473

Zonneveld BJM (2001) Nuclear DNA contents of all species of Helleborus discriminate between species and sectional divisions. Plant Syst Evol 229:125-130

Zonneveld BJM (2008) The systematic value of nuclear DNA content for all species of Narcissus L. (Amaryllidaceae). Plant Syst Evol 275:109-132

Zonneveld BJM (2009) The systematic value of nuclear genome size for all species of Tulipa L. (Liliaceae). Plant Syst Evol 281:217-245

Zonneveld BJM (2010) New record holders for maximum genome size in Eudicots and Monocots. J Bot :1-4 doi:101155/2010/527357

Zonneveld BJM (2010) Genome size in Hepatica Mill (Ranunculaceae) show a loss of DNA not a gain, in polyploids. J Bot:1-7 doi: $10.1155 / 2010 / 758260$

Zonneveld BJM (2011) Pine nut syndrome: A simple test for genome size of twelve pine nut producing trees links the bitter aftertaste to nuts of Pinus armandii Zucc ex Endl. Plant Syst Evol 297:201-206

Zonneveld BJM (2012) Conifer genome sizes of 172 species, covering 64 out of the 67 genera, range from 8 to 72 picogram. Nordic J Bot (in press)

Zonneveld BJM, Duncan GD (2010) Genome sizes of Eucomis L'Her. (Hyacinthaceae) and a description of the new species Eucomis grimshawii GD Duncan \& Zonneveld. Plant Syst Evol 284:99-109

Zonneveld BJM, Van Iren F (2001) Genome size and pollen viability as taxonomic criteria: Application to the genus Hosta. Plant Biol 3:176-185

Zonneveld BJM, Grimshaw JM, Davis AP (2003) The systematic value of nuclear DNA content in Galanthus. Plant Syst Evol 241:89-102 